\title{
Preparation of $\mathrm{Ca}-\alpha \mathrm{SiAlON}$ powder by reduction-nitridation in a gas mixture of $\mathrm{C}_{3} \mathrm{H}_{8}$ and $\mathrm{NH}_{3}$
}

\author{
Mikinori HOTTA, ${ }^{\dagger}$ Hideki KITA, Tomohiro YAMAKAWA, ${ }^{*}+$ Junichi TATAMI, ${ }^{*}$ \\ Katsutoshi KOMEYA* and Takeshi MEGURO*
}

\author{
Advanced Manufacturing Research Institute, National Institute of Advanced Industrial Science and Technology (AIST), \\ 2266-98 Shimo-Shidami, Moriyama-ku, Nagoya 463-8560, Japan \\ *Graduate School of Environment and Information Science, Yokohama National University, \\ 79-7 Tokiwadai, Hodogaya-ku, Yokohama 240-8501, Japan
}

\begin{abstract}
$\mathrm{Ca}-\alpha$ SiAION powders were synthesized from a $\mathrm{SiO}_{2}-\mathrm{Al}_{2} \mathrm{O}_{3}-\mathrm{CaCO}_{3}$ powder mixture by reduction-nitridation with $\mathrm{C}_{3} \mathrm{H}_{8}-\mathrm{NH}_{3}$ gas. Ca- $\alpha$ SiAION with small amounts of $A I N$ and $\beta$-SiAION phases was produced at $1450^{\circ} \mathrm{C}$ for 120 min. Angular particles and agglomerated and bonded particles with irregular shapes were formed. In the product prepared at $1450^{\circ} \mathrm{C}$ without any holding time, $\mathrm{Si}_{2} \mathrm{~N}_{2} \mathrm{O}$ was detected as an intermediate phase, in addition to the $\mathrm{Ca}-\alpha \mathrm{SiAION}, \beta$-SiAION and AIN phases. A large number of agglomerated and bonded particles were observed.
\end{abstract}

(c2012 The Ceramic Society of Japan. All rights reserved.

Key-words : SiAION, Powder, Reduction-nitridation, Gas, Morphology, Formation process

[Received December 13, 2011; Accepted February 2, 2012]

SiAlON ceramics possess high hardness and excellent oxidation and corrosion resistance. ${ }^{1-4)} \alpha-\mathrm{SiAlON}$ is a solid solution having a $\alpha-\mathrm{Si}_{3} \mathrm{~N}_{4}$ crystal structure, with some $\mathrm{Al}$ and $\mathrm{O}$ substituted for $\mathrm{Si}$ and $\mathrm{N}$ and some metal cations incorporated as a stabilizer. The general formula for $\alpha$-SiAlON is $\mathrm{M}_{m / v} \mathrm{Si}_{12-(m+n)^{-}}$ $\mathrm{Al}_{m+n} \mathrm{O}_{n} \mathrm{~N}_{16-n}$, where $v$ is the valency of the stabilizing cation M. M can be $\mathrm{Li}, \mathrm{Mg}, \mathrm{Ca}, \mathrm{Y}$, or most rare-earth elements. ${ }^{5)} \alpha$ SiAlON powders have been prepared by carbothermal reductionnitridation (CRN) of the $\mathrm{SiO}_{2}-\mathrm{Al}_{2} \mathrm{O}_{3}-\mathrm{M}_{x} \mathrm{O}_{y}$ system mixed with carbon powder as a reducing agent under flowing $\mathrm{N}_{2}$ gas. ${ }^{6}{ }^{6-12)}$ In our previous study, $\mathrm{Ca}-\alpha \mathrm{SiAlON}$ powders were prepared from mixtures of $\mathrm{SiO}_{2}, \mathrm{Al}_{2} \mathrm{O}_{3}, \mathrm{CaCO}_{3}$ and carbon powders by CRN. ${ }^{13)-16)}$ The powders prepared had hollow spheres composed of nanosized particles. ${ }^{13)}$ Solid spherical particles that consisted of a liquid phase containing $\mathrm{Si}, \mathrm{Al}, \mathrm{Ca}, \mathrm{O}$ were generated at the initial stage of the $\mathrm{CRN}$ process. As the reaction proceeded from the liquid phase to the crystalline $\mathrm{Ca}-\alpha \mathrm{SiAlON}$, the solid spheres changed into hollow spheres. ${ }^{14), 15)}$

High-purity and fine-grained AlN powders were obtained by gas reduction-nitridation (GRN) of fine-grained $\mathrm{Al}_{2} \mathrm{O}_{3}$ using a gas mixture of $\mathrm{C}_{3} \mathrm{H}_{8}$ and $\mathrm{NH}_{3}$ as a reduction-nitridation agent. ${ }^{17), 18)}$ This indicated that the resultant particles retained the morphology of the starting powders because of a gas-solid reaction between $\mathrm{Al}_{2} \mathrm{O}_{3}$ and $\mathrm{NH}_{3}$, and that the use of a hydrocarbon gas as reducing agent promoted more reduction-nitridation compared to the case of CRN with carbon powder.

In the present work, $\mathrm{Ca}-\alpha \mathrm{SiAlON}$ powders were prepared through GRN of a mixture of $\mathrm{SiO}_{2}, \mathrm{Al}_{2} \mathrm{O}_{3}$, and $\mathrm{CaCO}_{3}$ powders using a $\mathrm{C}_{3} \mathrm{H}_{8}-\mathrm{NH}_{3}$ gas mixture, and the crystalline phases and particle morphology of the products were investigated. The effect of hydrocarbon gas as a reducing agent on the particle morphology of the products was also discussed.

Corresponding author: M. Hotta; E-mail: mikinori-hotta@aist. go.jp

* Present address: Joining and Welding Research Institute, Osaka University, 11-1 Mihogaoka, Ibaraki, Osaka 567-0047, Japan
As starting materials, $\mathrm{SiO}_{2}$ (QS-102, Tokuyama Co., particle size: $0.005-0.05 \mu \mathrm{m}), \mathrm{Al}_{2} \mathrm{O}_{3}$ (AKP-50, Sumitomo Chemical Co., Ltd., $0.21 \mu \mathrm{m}$ ) and $\mathrm{CaCO}_{3}$ (Junsei Chemical Co., Ltd., $1.0 \mu \mathrm{m}$ ) powders were used. The proportions of these powders were adjusted so as to obtain a nominal composition of $\mathrm{Ca}_{1.0} \mathrm{Si}_{9.0} \mathrm{Al}_{3.0} \mathrm{O}_{1.0^{-}}$ $\mathrm{N}_{15.0}$ [i.e. $\mathrm{Ca}_{x} \mathrm{Si}_{12-3 x} \mathrm{Al}_{3 x} \mathrm{O}_{x} \mathrm{~N}_{16-x}(x=m / v=n)$ with $x=1.0$ ], which was the maximum content of $\mathrm{Ca}-\alpha \mathrm{SiAlON}$ phase in the products obtained by $\mathrm{CRN}$ of $\mathrm{SiO}_{2}-\mathrm{Al}_{2} \mathrm{O}_{3}-\mathrm{CaCO}_{3}$ powder mixtures with $x$ varying from 0.3 to $1.4 .{ }^{13)}$ The starting powders were mixed with a small amount of ethanol. The mixture was dried, sieved, placed in an $\mathrm{Al}_{2} \mathrm{O}_{3}$ boat, and heated in a horizontal electric furnace under a flowing gas mixture of $\mathrm{C}_{3} \mathrm{H}_{8}(20 \mathrm{~mL} / \mathrm{min})$ and $\mathrm{NH}_{3}(4 \mathrm{~L} / \mathrm{min})$ at a rate of $10^{\circ} \mathrm{C} / \mathrm{min}$ up to $1450^{\circ} \mathrm{C}$, for holding times of 0 to $120 \mathrm{~min}$. The crystalline phases that appeared in the specimens were identified by X-ray diffractometry (XRD). The content of the $\mathrm{Ca}-\alpha$ SiAlON phase was calculated from the XRD peak intensities. ${ }^{15)}$ Scanning electron microscopy (SEM) was used to characterize the particle morphology of the specimens.

Figure 1 shows the XRD pattern of the specimen prepared at $1450^{\circ} \mathrm{C}$ for $120 \mathrm{~min}$ by GRN. Ca- $\alpha$ SiAlON was detected as the major phase, and AIN and $\beta$-SiAlON as minor phases, the relative amounts being 80,15 and $5 \%$, respectively. In our previous study, $\mathrm{CRN}$ of $\mathrm{SiO}_{2}-\mathrm{Al}_{2} \mathrm{O}_{3}-\mathrm{CaCO}_{3}$ powder mixtures yielded no $\beta$-SiAlON. Instead, $85-90 \% \mathrm{Ca}-\alpha$ SiAlON and $10-15 \%$ AlN were found in the specimens prepared at $1450^{\circ} \mathrm{C}$ for $120 \mathrm{~min}$ at the composition $x=1.0$ and a carbon content 1.2 to 2.0 times the stoichiometric value. ${ }^{13), 16)}$ Moreover, in the specimen prepared at the stoichiometric carbon content, the intermediate phases of $\mathrm{Si}_{2} \mathrm{~N}_{2} \mathrm{O}, \mathrm{SiAl}_{7} \mathrm{O}_{2} \mathrm{~N}_{7}$ and AlN were generated. ${ }^{16)}$ In the present study, the $\beta$-SiAlON phase presumably formed as a result of the difference in the evaporation rate of $\mathrm{SiO}$ gas from $\mathrm{SiO}_{2}$ by using carbon powder versus a hydrocarbon gas as reducing agent. A flow of $20 \mathrm{~mL} / \mathrm{min}_{3} \mathrm{H}_{8}$ and $4 \mathrm{~L} / \mathrm{min}$ $\mathrm{NH}_{3}$ was sufficient to produce $\mathrm{Ca}-\alpha$ SiAlON through GRN of the $\mathrm{SiO}_{2}-\mathrm{Al}_{2} \mathrm{O}_{3}-\mathrm{CaCO}_{3}$ powder mixture.

Figure 2 shows the SEM micrographs of the specimens prepared at $1450^{\circ} \mathrm{C}$ for $120 \mathrm{~min}$ by GRN. Angular particles with 


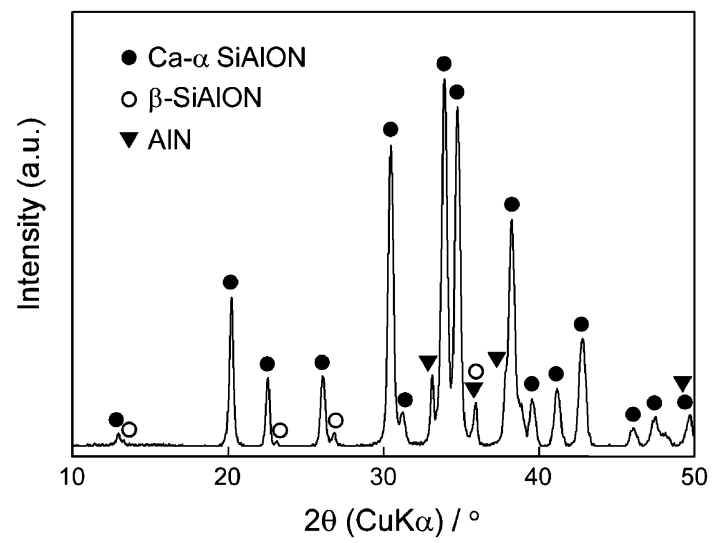

Fig. 1. XRD pattern of the specimen prepared by $\mathrm{GRN}$ at $1450^{\circ} \mathrm{C}$ for $120 \mathrm{~min}$
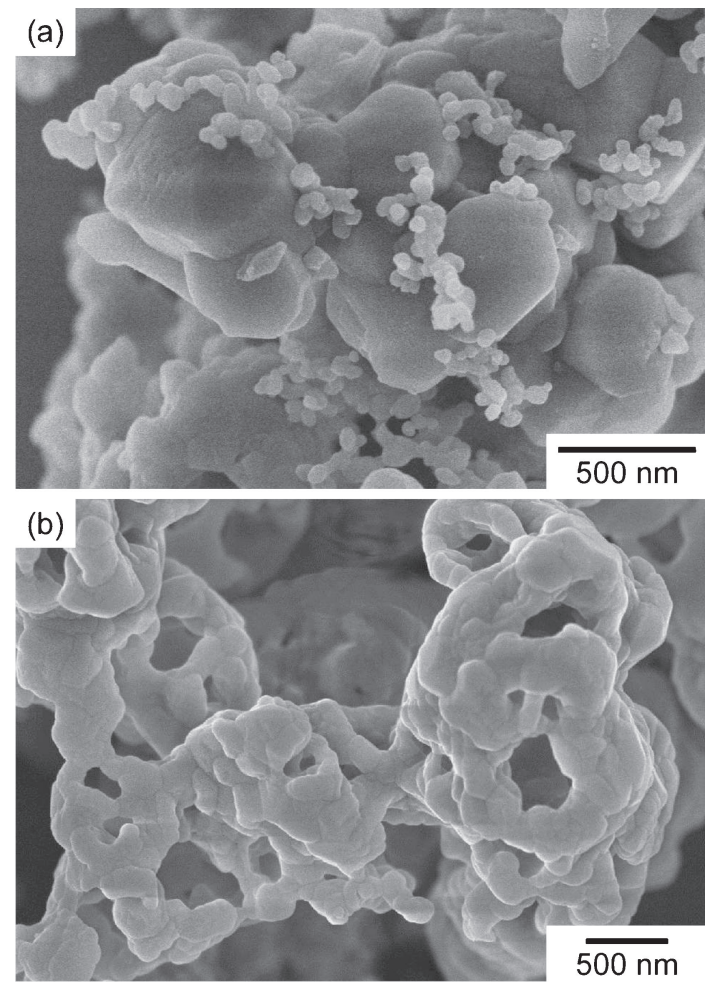

Fig. 2. SEM micrographs of the specimen prepared by GRN at $1450^{\circ} \mathrm{C}$ for $120 \mathrm{~min}$.

a diameter of around $0.5 \mu \mathrm{m}$ [Fig. 2(a)], and agglomerated and bonded particles with irregular shapes [Fig. 2(b)] were observed. Fine particles with diameters of less than $100 \mathrm{~nm}$ were also present [Fig. 2(a)]. Hollow spherical particles, obtained by CRN of $\mathrm{SiO}_{2}-\mathrm{Al}_{2} \mathrm{O}_{3}-\mathrm{CaCO}_{3}$ powder mixtures in our previous study, were hardly observed. ${ }^{13), 15)}$

In order to analyze the formation process of $\mathrm{Ca}-\alpha$ SiAlON through GRN of the $\mathrm{SiO}_{2}-\mathrm{Al}_{2} \mathrm{O}_{3}-\mathrm{CaCO}_{3}$ powder mixture in $\mathrm{C}_{3} \mathrm{H}_{8}-\mathrm{NH}_{3}$ gas, the powder mixture was heated to $1450^{\circ} \mathrm{C}$, but not held at this temperature, and the resulting crystalline phases and microstructure were characterized. Figure 3 shows the XRD pattern of the specimen prepared by GRN at $1450^{\circ} \mathrm{C}$ without any holding time. The $\mathrm{Si}_{2} \mathrm{~N}_{2} \mathrm{O}$ phase was identified, in addition to $\mathrm{Ca}-\alpha \mathrm{SiAlON}, \beta$-SiAlON and AlN. In our previous work, $\mathrm{Si}_{2} \mathrm{~N}_{2} \mathrm{O}$ was also confirmed as an intermediate phase in the

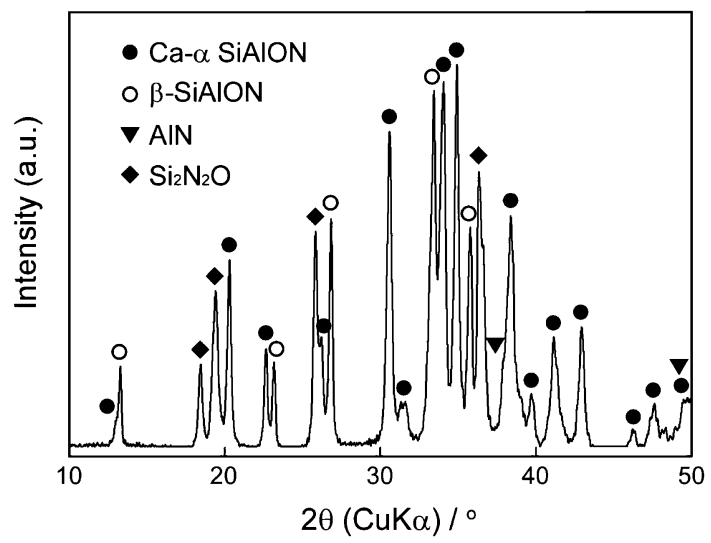

Fig. 3. XRD pattern of the specimen prepared by GRN at $1450^{\circ} \mathrm{C}$ without any holding time.

formation of $\mathrm{Ca}-\alpha$ SiAlON through $\mathrm{CRN}$ of $\mathrm{SiO}_{2}, \mathrm{Al}_{2} \mathrm{O}_{3}$ and $\mathrm{CaCO}_{3}$ powders mixed with carbon powder under flowing $\mathrm{N}_{2}{ }^{14), 15)}$ The $\beta$-SiAlON to Ca- $\alpha$ SiAlON XRD peak intensity ratio was higher in the specimens prepared at $1450^{\circ} \mathrm{C}$ without any holding time than in that prepared with a 120 -min holding time, indicating the higher proportion of $\beta$-SiAlON in the former specimen. In the specimens prepared by $\mathrm{CRN}$ at $1450{ }^{\circ} \mathrm{C}$ without any holding time, an amorphous shoulder was observed at low $2 \theta$ values in the XRD patterns, ${ }^{14), 15)}$ while no amorphous shoulder was detected in specimens prepared by GRN. The XRD peaks of the crystalline phases in the specimens prepared by GRN at $1450^{\circ} \mathrm{C}$ without any holding time were higher and sharper than those obtained in the case of $\mathrm{CRN} .{ }^{14), 15)}$ Thus, the reductionnitridation of the $\mathrm{SiO}_{2}-\mathrm{Al}_{2} \mathrm{O}_{3}-\mathrm{CaCO}_{3}$ mixture to $\mathrm{Ca}-\alpha$ SiAlON via GRN with $\mathrm{C}_{3} \mathrm{H}_{8}-\mathrm{NH}_{3}$ gas presumably proceeded faster than that by $\mathrm{CRN}$ with carbon powder and $\mathrm{N}_{2}$ gas. Furthermore, the XRD peaks of Ca- $\alpha$ SiAlON in the specimen prepared at $1450^{\circ} \mathrm{C}$ without any holding time shifted to higher $2 \theta$ values compared to those obtained in the case of the reaction at $1450^{\circ} \mathrm{C}$ with a 120 -min holding time. This would suggest that the $\mathrm{Ca}, \mathrm{Al}$ and $\mathrm{O}$ content of the $\mathrm{Ca}-\alpha \mathrm{SiAlON}$ increased as the holding time was increased from 0 to $120 \mathrm{~min}$, because the lattice constant was increased by incorporation of $\mathrm{Ca}$ into the $\alpha$-SiAlON structure, and substitution of $\mathrm{Al}$ and $\mathrm{O}$ for $\mathrm{Si}$ and $\mathrm{N}$.

Figure 4 shows the SEM micrographs of the specimen prepared by GRN at $1450^{\circ} \mathrm{C}$ without any holding time. Agglomerated and bonded particles, composed of a large number of particles with a diameter of less than $0.5 \mu \mathrm{m}$, can be observed. In the case of CRN, solid spherical particles were seen in specimens prepared at $1450^{\circ} \mathrm{C}$ without any holding time. ${ }^{14), 15)}$ The XRD pattern in Fig. 3 suggests that the formation process of $\mathrm{Ca}-\alpha$ SiAlON powder from a $\mathrm{SiO}_{2}-\mathrm{Al}_{2} \mathrm{O}_{3}-\mathrm{CaCO}_{3}$ mixture is nearly the same both in GRN and CRN. The difference in particle morphology between the specimens prepared at $1450^{\circ} \mathrm{C}$ for $120 \mathrm{~min}$ by GRN versus CRN may be attributable to the different reducing agents used in the two cases. In the case of CRN with carbon powder as the reducing agent, spheres consisting of a $\mathrm{Si}-\mathrm{Al}-\mathrm{Ca}-\mathrm{O}$ liquid phase were formed during the initial stage of the reaction, because of the poor wettability between the liquid and carbon. The solid spheres subsequently changed into hollow spheres as the reduction-nitridation reaction proceeded. ${ }^{14)}$ In the case of GRN with $\mathrm{C}_{3} \mathrm{H}_{8}$ gas, on the other hand, the $\mathrm{Si}-\mathrm{Al}-\mathrm{Ca}-\mathrm{O}$ liquid phase did not lead to the formation of spheres, because the hydrocarbon gas was not conducive to the formation of spherical particles. Hence, agglomerated and bonded particles would be 


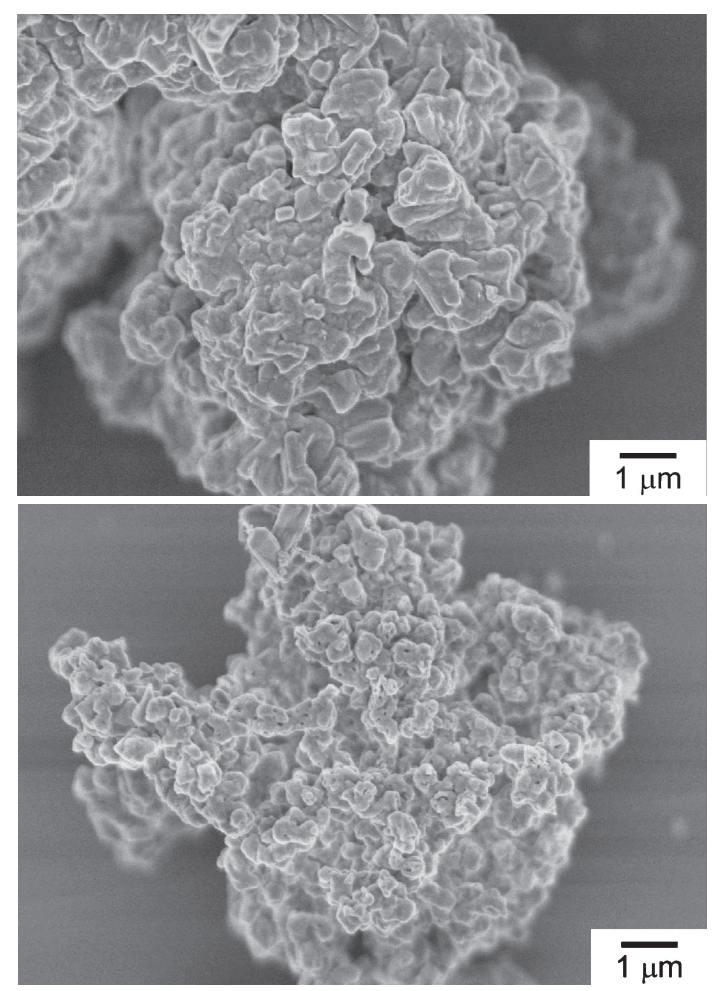

Fig. 4. SEM micrographs of the specimen prepared by $\mathrm{GRN}$ at $1450^{\circ} \mathrm{C}$ without any holding time.

generated in the initial stage of the GRN process, and $\mathrm{Ca}-\alpha$ SiAlON would be produced while maintaining the particle morphology (Figs. 2 and 4).

In summary, $\mathrm{Ca}-\alpha \mathrm{SiAlON}$ powders were prepared through GRN of a $\mathrm{SiO}_{2}-\mathrm{Al}_{2} \mathrm{O}_{3}-\mathrm{CaCO}_{3}$ powder mixture under flowing $\mathrm{C}_{3} \mathrm{H}_{8}-\mathrm{NH}_{3}$, and the crystalline phases and microstructure of the products were studied. $\mathrm{Ca}-\alpha$ SiAlON, AlN and $\beta$-SiAlON phases were found in the specimens prepared at $1450^{\circ} \mathrm{C}$ for $120 \mathrm{~min}$. The $\mathrm{Ca}-\alpha \mathrm{SiAlON}$ content was $80 \%$. Angular particles, and agglomerated and bonded particles were observed in the final product. In the specimen prepared at $1450^{\circ} \mathrm{C}$ without any holding time, $\mathrm{Si}_{2} \mathrm{~N}_{2} \mathrm{O}$ was detected as an intermediate phase.
Agglomerated and bonded particles were observed in the product. The spherical particles generated by $\mathrm{CRN}$ of $\mathrm{SiO}_{2}-\mathrm{Al}_{2} \mathrm{O}_{3}-\mathrm{CaCO}_{3}$ powders mixed with carbon powder under flowing $\mathrm{N}_{2}$ were largely absent in the specimens prepared by GRN.

\section{References}

1) C. A. Wood, H. Zhao and Y.-B. Cheng, J. Am. Ceram. Soc., 82, 421-428 (1999).

2) C. L. Hewett, Y.-B. Cheng, B. C. Muddle and M. B. Trigg, J. Am. Ceram. Soc., 81, 1781-1788 (1998).

3) C. L. Hewett, Y.-B. Cheng, B. C. Muddle and M. B. Trigg, J. Eur. Ceram. Soc., 18, 417-427 (1998).

4) I.-W. Chen and A. Rosenflanz, Nature, 389, 701-704 (1997).

5) S. Hampshire, H. K. Park, D. P. Thompson and K. H. Jack, Nature, 274, 880-882 (1978).

6) M. Mitomo, M. Takeuchi and M. Ohmasa, Ceram. Int., 14, 43-48 (1988).

7) J. W. T. van Rutten, R. A. Terpstra, J. C. T. Heijde, H. T. Hintzen and R. Metselaar, J. Eur. Ceram. Soc., 15, 599-604 (1995).

8) T. Ekström, Z.-J. Shen, K. J. D. MacKenzie, I. W. M. Brown and G. V. White, J. Mater. Chem., 8, 977-983 (1998).

9) C. Zhang, K. Komeya, J. Tatami, T. Meguro and Y.-B. Cheng, J. Eur. Ceram. Soc., 20, 1809-1814 (2000).

10) J. Y. Qiu, J. Tatami, C. Zhang, K. Komeya, T. Meguro and Y.-B. Cheng, J. Eur. Ceram. Soc., 22, 2989-2996 (2002).

11) Y.-B. Cheng, M. R. Terner, W. W. Chen and P. L. Wang, Key Eng. Mater, 264-268, 781-786 (2004).

12) M. R. Terner and Y.-B. Cheng, Proceedings Int. Conf. Adv. Mat. Proc 3, Melbourne 2004 (2004) pp. 50-51.

13) K. Komeya, C. Zhang, M. Hotta, J. Tatami, T. Meguro and Y.-B. Cheng, J. Am. Ceram. Soc., 83, 995-997 (2000).

14) M. Hotta, J. Tatami, K. Komeya, C. Zhang, T. Meguro, M. R. Terner and Y.-B. Cheng, J. Am. Ceram. Soc., 91, 860-864 (2008).

15) M. Hotta, J. Tatami, C. Zhang, K. Komeya, T. Meguro, M. R. Terner and Y.-B. Cheng, Ceram. Int., 36, 1553-1559 (2010).

16) M. Hotta, J. Tatami, K. Komeya, T. Meguro and Y.-B. Cheng, J. Ceram. Soc. Japan, 118, 827-829 (2010).

17) T. Yamakawa, J. Tatami, T. Wakihara, K. Komeya, T. Meguro and K. J. D. Mackenzie, J. Am. Ceram. Soc., 89, 171-175 (2006).

18) T. Suehiro, J. Tatami, T. Meguro, S. Matsuo and K. Komeya, J. Eur. Ceram. Soc., 22, 521-526 (2002). 